\title{
Meet the Vikings: for real!
}

Peter Pentz ${ }^{1, *}$, Jeanette Varberg ${ }^{1} \&$ Lasse Sørensen ${ }^{1}$

The National Museum in Copenhagen responds to Søren Sindbak's (2019) review of their revitalised Viking gallery, arguing that the new 'Meet the Vikings' exhibit increases public accessibility and engagement, while also reflecting contemporary research into Viking life.

Keywords: Copenhagen, National Museum, Vikings, public engagement

In the April issue of Antiquity, Søren Sindbæk reviewed the revitalisation of our Viking galleries at the National Museum (Sindbæk 2019). He raised a series of interesting questions about archaeology and public display, and concluded that the museum has stumbled with this exhibition, showing carelessness towards its core values.

As an institution, the museum must move with the times, and with these shifts come changes in values. The original Viking gallery at the National Museum in Copenhagen was completed in 2007. Despite the splendour of the artefacts in the exhibition, they were, as Sindbæk notes, somewhat disregarded by the public. The approach of the exhibition was very much 'letting the artefacts speak for themselves', with a moderate level of supporting description. While the display was intended to be aesthetically attractive, the presentation of the precious silver and golden artefacts in fact appeared sterile and sanitised. While it may have piqued academic interest, the display had less of an impact on visitors, perhaps because a rather broad knowledge of the Viking Age was required to appreciate it. Their understanding of the period after their visit remained obscure; in fact, many visitors called for a more elaborate Viking gallery. It was clear that even with a good understanding of visitors' expectations, the museum often fell short of meeting them.

The Viking Age gallery was situated at the end of the prehistoric exhibitions, visitors having started their journey in the Ice Age, before passing through the Bronze and Iron Ages. We wished to break with this traditional chronological approach. Feedback from visitors clearly revealed that encountering galleries in sequence was not important to them; consequently, the Viking gallery can now be entered either from the Iron Age display or directly from the museum's entrance hall. In this way, we also hope to signal that we acknowledge the Viking Age as a period in its own right.

Sindbæk regrets that the reopening of the gallery was a media event for the latest season of the TV series Vikings. In his view this revealed the museum's desire for publicity. We do not mind publicity, but more importantly, should we-as professionals-really feel uncomfortable with Vikings? Shortly after the programme launched in 2003, Neil Price rightly stated that all Viking scholars would do well to acknowledge it, in view of its impact and its basis in scholarly work (Price 2015). Themes shown in Vikings such as face paint and female

1 The National Museum, Frederiksholms Kanal 12, DK-1220 Copenhagen, Denmark

* Author for correspondence (Email: peter.pentz@natmus.dk)

(C) Antiquity Publications Ltd, 2019

ANTIQUITY 93 369, e19 (2019): 1-5

https://doi.org/10.15184/aqy.2019.80 


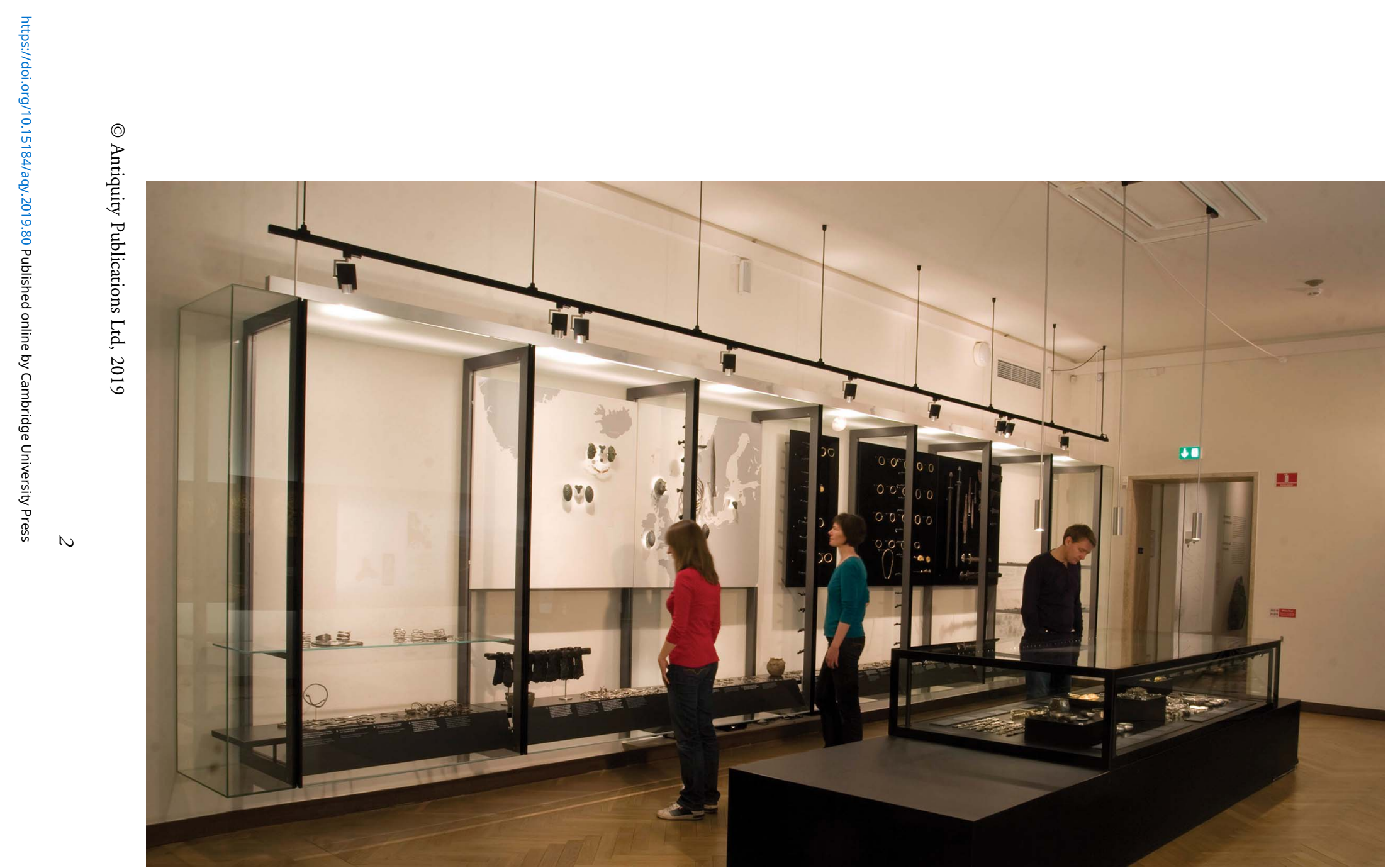


identity—characters include female warriors and berserkers—are exactly those that scholars have explored in the last two decades. These themes also form significant elements of the new Viking gallery. Such ideas would have been regarded as dubious only 20 years ago.

In order to create a relaxed and enjoyable environment that would stimulate learning by encouraging the public to engage with the artefacts, the designer Jim Lyngvild was involved in the redesign. In an atmosphere of mutual respect for our respective professions, we- the curators - and Lyngvild wished to create a framework for more interactive communication. As acknowledged by Sindbæk, Lyngvild has managed to create an attractive gallery in which the visitor is invited to engage in a dynamic dialogue with the artefacts.

It has long been recognised that people want to take an active role in interpreting the past. The past presented 'as it was' through a single lens of interpretation that excludes other voices easily becomes arrogant. Archaeological knowledge is acquired and interpreted within the framework of current interests and values, and archaeologists produce different interpretations from the same material.

"The fictional is well presented, the combination with the artefacts great. Engaging?" (visitor comment). 'Meet the Vikings' is not supposed to be a matter of merely looking and learning. It is also an exercise in imagination, in 'how the past could have been' in the conceptual imagery of the visitors. In this way, the visitor becomes a producer rather than simply a consumer, an active agent of interpretation.

Encouraging visitors to engage with the Viking Age requires different tools. In 'Meet the Vikings', one method is the large photographs of 'Vikings', which feature re-enactors and models skilfully posed and photographed by Lyngvild. Sindbæk rhetorically asks what a steppe nomad, wearing a sabretache at his belt, is doing in a Viking gallery. Such pouches have actually been found in Birka together with other Magyar equipment (HedenstiernaJonson 2009: 52-53). Whatever the degree of authenticity of their costume and outfits, however, this is not the point! There is no steppe nomad in the exhibition, it is a re-enactor. These photographs do not claim to be authentic. The steppe nomad is a character and plays his part well; the fierce female warrior is in reality Lyngvild's hairdresser.

"The ring!! On the merchant's wife's finger!! With a Bronze Age motif!! Embarrassing!!! Embarrassing!!! Why not a smartphone?! Who is responsible?!!" (comment from an upset but engaged visitor). Visitors to our galleries are asked to use their imagination and are invited to both construct and de-construct biographical fictions of the 'Vikings'. Some visitors, such as Sindbæk, expend effort trying to expose the 'fraud' when confronted by Viking characters sporting contemporary objects. We argue that such detective work is fun. Another way of looking at it is that the modern ring of the merchant's wife, noted by Sindbæk, can be seen as an example of how past and present entwine. Such hybridity may include anachronisms, but serves to engage the audience in an interpretive and critical process, to stimulate the imagination of the viewer and to invite questioning. Our re-enactors have used and combined things from different epochs, just as Vikings used things that were both part of their past and their present. Each re-enactor offers their own version of the past. Their modern identities actually make them authentic intermediaries; they serve to arouse interest in — rather than to monopolise-interpretation and meaning.

The inclusion of re-enactors and of dramatisation in museum galleries is hardly a novelty. Founded in 1984, the Jorvik Viking Centre in York was one of the first exhibitions to make

(C) Antiquity Publications Ltd, 2019 
Peter Pentz et al.

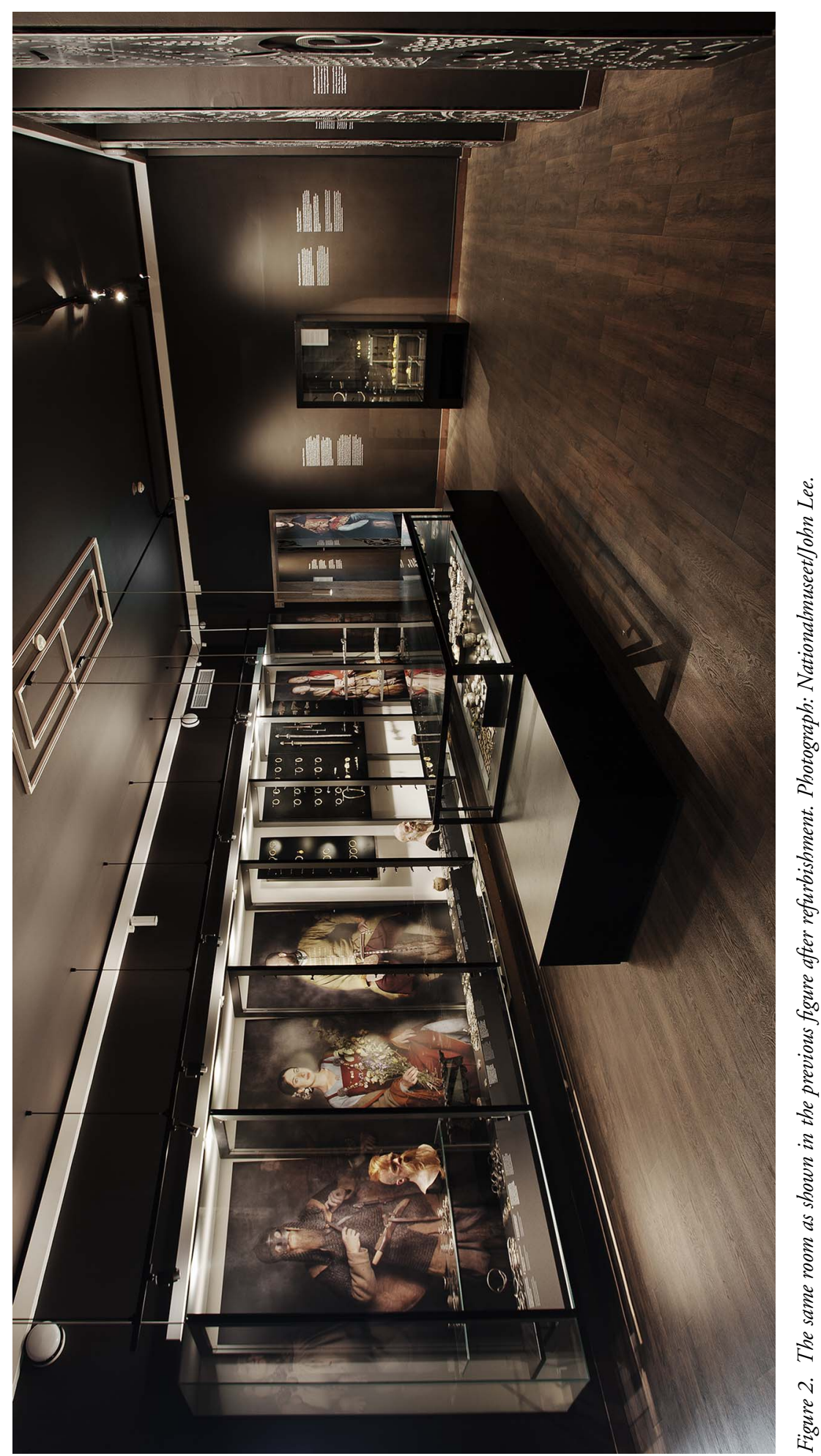

(C) Antiquity Publications Ltd, 2019 
intensive use of staging, even including elements from amusement parks to create an entertaining trip in a time machine to a reanimated Viking settlement populated by mannequins. The Jorvik Centre offered a respectable mixing of authenticity and entertainment. The centre has recently re-opened, with an updated historical interpretation focusing on York as a cultural 'melting pot' of the tenth century. Ideas about the past change, so do displays.

Our visitors are not mindless, they do not come to us for indoctrination. We do not think that they expect the museum to uphold standards of one, and only one, culturally defined 'truth'. Rather, they visit us with the expectation that we will challenge such a 'truth'. For the authentic experience, we argue, challenge is essential.

Sindbæk calls for more information in the gallery on aspects left unrepresented, such as ships and sailing. There are several aspects omitted, but the intension was never to create an encyclopaedic exhibition. The area covered by the Viking gallery is restricted, but we hope to open a new and larger Viking exhibition in 2021.

We have experienced an overwhelming interest in 'Meet the Vikings' and an extensive increase in visitor numbers. Half of the visitors had either not been to the museum before, or not in recent years. We are happy to welcome first-time visitors and even more pleased that they respond with enthusiasm. More than half of the visitors say they learned something new, and 70 per cent have been inspired to learn more about the Vikings. The majority of the visitors who were asked said that they would recommend the gallery to family and friends (numbers are based on answers from 346 respondents collected in the period from 6 December 2018 to 19 January 2019 by the National Museum).

It is true, as Sindbæk argues, that museums struggle to adjust to a changing world and to different values. Museums are no longer ivory towers where relics of distant ages are safely kept. Neither are they universities, and museums still form the main institutional link between archaeology and the wider society. Museums must respond to the changing social environment that they are part of, or become obsolete. The National Museum acknowledges this and our prime responsibilities are not only to the collections, but also the audience.

\section{References}

Hedenstierna-Jonson, C. 2009. Magyar-RusScandinavia. Cultural exchange in the early medieval period. Situna Dei 2009: 47-56.

Price, N. 2015. From Ginnungagap to the

Ragnarök: archaeologies of the Viking worlds, in

U. Pedersen, M. Moen, I. Axelsen, H. Berg \&
M.H. Eriksen (ed.) Viking worlds: things, spaces and movement: 1-10. Oxford: Oxbow.

SindвÆK, S.M. 2019. 'Meet the Vikings'-or meet halfway? The new Viking display at the National Museum of Denmark in Copenhagen. Antiquity 367: 256-59.

https://doi.org/10.15184/aqy.2019.1

Received: 4 April 2019; Revised: 5 April 2019; Accepted: 5 April 2019 